\title{
Study on the Efficiency of the Vegetables Freezing Process
}

\author{
Simona Paulikienè, Algirdas Raila \\ Institute of Energy and Biotechnology Engineering, Aleksandras Stulginskis University, Kaunas, Lithuania
}

cross $^{\text {ref }}$ http://dx.doi.org/10.5755/j01.erem.69.3.6064

(Received in December, 2013; accepted in September, 2014)

\begin{abstract}
Changes taking place during the storage of the products of vegetable origin are inevitable. Products can deteriorate and change their shelf appearance, nutritional value, texture, taste and aroma. Freezing is one of the most appropriate technological operations for the product storage. By freezing products of vegetable origin, cleaner production technology can be used to consume less energy and to preserve quality of the product as well as valuable nutritional/ biologically active substances.

The study of vegetable freezing process was carried out by freezing red beets. Beetroot was frozen in a chamber with controlled climatic environment - the Feutron.

A portion of moisture content always evaporates from products of vegetable origin at freezing. Air flow velocity has a great influence on freezing rate of vegetables. Intensity of moisture evaporation also increases up to the moment of freezing-up of the surface layers.

Intensity of retardation of the evaporation process depends on a peel and on stomata on it. Moisture evaporation's retardation rate of the red beet peel $\varepsilon_{\text {evp.ap }}=0,50 \pm 0,02$. When air velocity was $0,15 \mathrm{~m} / \mathrm{s}-\varepsilon_{\text {evp }}$ varied from 0,47 to 0,53 , whilst at the air flow velocity $0,65 \mathrm{~m} / \mathrm{s}-\varepsilon_{\mathrm{evp}}=0,37-0,45$.

Purpose of the study - to analyse the freezing process of vegetables (by the red beetroot example) under the influence of different environment factors.
\end{abstract}

Keywords: freezing, freezing rate, moisture transfer, beetroot

\section{Introduction}

After the harvest, vegetable foods are consumed fresh, frozen or preserved in other ways [1]. Changes during storage are unavoidable because of physical, biochemical and microbiological activities [1, 2, 3, 16]. These processes can result in degeneration of the product nutritional value, consistency, taste and aroma [3]. To store the product for a longer period of time, it is subjected to cold.

Conservation by freezing is one of the best and most reliable ways of product protection against deterioration. When subjecting to freezing, nutritional value and quality of the rapidly deteriorating products is preserved [3].

In terms of the energy costs and product quality ratio, a product changes less during freezing and its quality remains higher as compared to drying or preservation in high temperature, whereas power consumption is relatively low [4].

According to data published by Swedish scientists, freezing of one ton of raw materials to - $18^{\circ} \mathrm{C}$ costs 2,3 relative monetary units, whilst keeping it (at $-18{ }^{\circ} \mathrm{C}$ ) costs 0,05 relative monetary units per day. The energy requirements for conservation by freezing are 2,5 times less than for pasteurization and 3 times less than for sterilisation. Although fruit drying consumes less energy; frozen products are characterized by their nutritional value and perfectly preserved taste [5].

For freezing products of vegetable origin cleaner production technology can be used to save energy and to ensure quality of the product (by preserving nutritional and biologically active substances).

Frozen berries, fruits and vegetables have their market in public catering institutions, confectionery shops and retail trade. Frozen products are in demand not only in Lithuania, but in other countries as well $[2,3,5]$.

Several technologies can be used for freezing of agricultural cropping products. Depending on the technology used, quality of frozen food can vary [4]. 
Despite a particular chosen technology, the primary goal is to keep food products unchanged as long as possible.

Research had shown that the consistency, flavour characteristics and texture have been preserved in the best way when liquefied gases were used [5, 14].

According the research conducted by Abreu, Gonçalves, Brandao, and Silva, significant changes have not observed both in colour and vitamin $\mathrm{C}$ content of frozen broccoli [15].

The research results published by $\mathrm{J}$. Kondratowicz and P. Matusevičius confirmed that good quality of frozen products correspond to ice crystals' formation. When temperature drops below the cryoscopic point and a lot of ice crystals are formed in the centre of the crystallisation, when more crystallization centres appear at higher temperature, then formation of the smaller ice crystals takes place [14].

The size of ice crystals depends on quantity of crystal elements - centers. At slow freezing, less crystal nucleus is developed and ice crystals are bigger, whereas at rapid freezing, more small crystals are formed and damage to cell walls is lower [7, 8, 9].

During long time storage of juicy agricultural products (fruits and vegetables) in a stock, significant amount of its moisture is lost. In contrast to grains, vegetables cannot restore the turgor or absorb moisture from environment. Turgor (condition of cell wall's tension, which occurs due to osmotic pressure and firmness of a cell membrane) helps to keep the shape of agricultural products [10]. Turgor is an important quality component of most of the fruits and vegetables [17]. When turgor decreases, a cell loses its solidity and wilting of products starts along with reduced resistance to diseases.

Since a plant regularly releases breathing energy during decompositions of accumulated nutrients, its equilibrium temperature in wet ambient air is somewhat higher than ambient air temperature around a product. This difference of temperatures causes moisture evaporation out to the environmen, even though relative air humidity is equal to $100 \%$ [11].

Moisture evaporated from agricultural products can be calculated by using Dalton's equation, i.e. by entering the correction factor $\varepsilon_{\text {evp }}$ that estimates the surface area, through which the moisture exchange can take place $[11,12]$ :

$W=\beta A \varepsilon_{\text {evp }}\left(p_{p r}-p_{p r . o} \cdot \varphi\right) \tau$

Where: $\quad W$-amount of evaporated moisture, $\mathrm{kg}$;

$\beta$ - moisture exchange rate, $\mathrm{kg} /\left(\mathrm{m}^{2} \cdot \mathrm{Pa} \cdot \mathrm{s}\right)$;

$A$ - surface area, $\mathrm{m}^{2}$;

$\varepsilon_{\text {evp }}$ - potential evaporation rate from a product as part of figure one (cortical surface area involved in moisture exchange);

$p_{p r}-$ partial pressure of saturated vapour to the product surface, $\mathrm{Pa}$;

$p_{\text {pro }}$ - partial pressure of water vapour in ambient air, $\mathrm{Pa}$;

$\varphi$ - relative humidity of ambient air as part of figure of one; $\tau$ - time, $\mathrm{s}$.

Juicy agricultural products cannot absorb moisture from environment, because vapour pressure of water in intercellular space is equal or close to the saturated vapour pressure at particular temperature and partial pressure of water vapour in the environment as a rule is lower than pressure of saturated vapour and equals to it only occasionally.

The objective of the study is to analyse the freezing process of vegetables (red beetroots) under the influences of different environment factors.

The tasks:

1. To determine the effects of air flow velocity and air temperature at freezing rate;

2. To determine influence of the freezing process on moisture evaporation.

\section{Object of the study and methods}

\subsection{Object of the study}

The vegetables freezing tests were carried out on red beets stored in a stock at temperature $3-4{ }^{\circ} \mathrm{C}$ and at relative air humidity $95-98 \%$. Red beets were of uniform weight and similar shape i.e. round, $7-8 \mathrm{~cm}$ in diameter.

\subsection{The test methods}

To determine intensity of moisture evaporation from a product at different intensity of cold air flow at the surface of a product, the test has been made (Fig. $1)$

We have used climatic test chamber Feutron KPK 600 (4) and put a stand with three cylinders (2) in it. Each cylinder had a fan on its top (3) and rotation speed of fans was set separately with rheostat by changing electric voltage. Three test objects (red beetroots) (1) have been placed in each cylinder, two temperature sensors were stuck into one beetroot (5) one sensor was inserted into a centre of the root and the other into the surface layer. Three beetroots were kept in the climatic test chamber beside the cylinders. The $8^{\text {th }}$ temperature sensor measured air temperature in a chamber. All eight temperature sensors were connected to a data acquiring device ALMEMO 3290-8 (6) and all data was stored. The device was programmed to record data every 5 minutes. Data had been transferred to a computer (7) after the tests. 


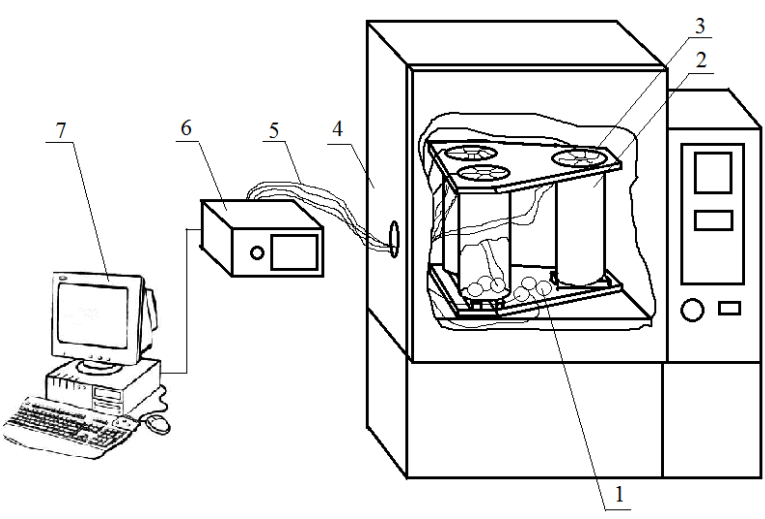

Fig. 1. Scheme of a test bench for estimating the intensity of moisture evaporation from a product: 1 - research object (red beets); 2-cylinder, 3 - the fans 4 - the climatic test chamber; 5 - sensors, 6 - measuring and data acquiring device; 7 - computer-program AMR-Control

To evaluate intensity of moisture evaporation during freezing, all red beets have been weighed both at the beginning and at the end of the test as well as during freezing every 5 hours per day. Variation of the objects mass was estimated by weighing samples repeatedly and the test was finished when they had reached the preset freezing temperature.

The test had shown trends of freezing rate and intensity of moisture evaporation from the samples at different velocities of air flow.

We had measured air flow velocity in cylinders with vane anemometer FVA 915 - SMA1 Zahler R1E4.

Temperature in the chamber changed the following way: on the first day set temperature was -2 ${ }^{\circ} \mathrm{C}$, the second day $--12{ }^{\circ} \mathrm{C}$ and on the third day --22 ${ }^{\circ} \mathrm{C}$. In the morning, midday and in evening of each day, the beetroots were taken out of the climatic chamber and weighed on electronic scales SCALTEC SPO 51. The values have been recorded after every measurement. When the beetroots had reached the preset minimal temperature below zero, they were left to thaw. The tests have been conducted in four repetitions.

Additionally, the test was carried out with set temperature in climatic chamber $-22{ }^{\circ} \mathrm{C}$ to determine the points of crystallization process.

Mass losses of beetroots have been recalculated for $1 \mathrm{~kg}$ :

$\Delta m=\frac{\Delta m_{\text {proc }} \cdot 1000}{100}$

Where: $\Delta m$ - weight change of a product, $\mathrm{g} / \mathrm{kg}$; $\Delta m_{\text {proc }}$ - mass change in $\%$, calculated by the formula:

$\Delta m_{\text {proc }}=\frac{m_{p r}-m_{g a l}}{m_{p r}} \cdot 100 \%$

Where: $\quad m_{p r}-$ initial weight of product, g;

$m_{g a l}$ - weight of product at particular temperature,

g.
The tests on the whole and peeled beetroot have been carried out using the above presented method.

Relationship between evaporation potential of a peel on a whole beetroot and of a peeled (a peel was removed) beetroot was calculated by a formula:

$$
\varepsilon_{e v p}=\frac{\Delta m}{\Delta m_{n u l}}
$$

Where: $\varepsilon_{\text {evp }}$ - potential evaporation rate from a product as part of figure of one (surface area of skin involved in moisture exchange);

$\Delta m$ - mass change of a whole beetroot, $\mathrm{g} / \mathrm{kg}$;

$\Delta m_{n u l}$ - mass change of a peeled beetroot (without a peel), $\mathrm{g} / \mathrm{kg}$.

Turgor recovery test has been carried out to determine moisture losses from the product during the storage. The turgor test has been carried out on the beetroot (T2) stored in normal conditions at 3-4 ${ }^{\circ} \mathrm{C}$, the beetroot (T1) stored one day in the climatic chamber at $-2{ }^{\circ} \mathrm{C}$ and the beetroot (T3) that had just been dug out from the soil.

9 cups of water have been used in a test. Slices of equal thickness have been cut from the middle of both beets and dried gently with a napkin. The dried slices have been weighed and the values have been recorded. The slices have been dipped in glasses with water for 3 hours. After each hour, slices have been removed, gently dried with a napkin, weighed and the data was recorded. Afterwards, the slices have been dipped back into the water. The records have been entered into Microsoft Excel data processor for further calculations. The restored beetroot moisture content was calculated as equivalent to $1 \mathrm{~kg}$ by the formula (2).

Percentage increase in weight of the sample is calculated by the formula:

$$
\Delta m_{p r o c}=\frac{m_{g a l}-m_{p r}}{m_{g a l}} \cdot 100 \%
$$

Where: $m_{p r}-$ initial weight of product, $\mathrm{g}$; $m_{\text {gal }}$ - final weight of product, $\mathrm{g}$.

\section{Results of the study and discussion}

\subsection{Influence of an air flow velocity on freezing rate and on intensity of moisture evaporation}

Results of experimental research of freezing process are shown in Fig. 2, where vegetables (red beets) have been frozen at different air flow velocities and at given difference of temperatures. Duration of the test was 25 hours. Temperature in the climatic chamber was $-22{ }^{\circ} \mathrm{C}$. The frozen beetroots were left to thaw with the stuck temperature sensors for temperature recording. 


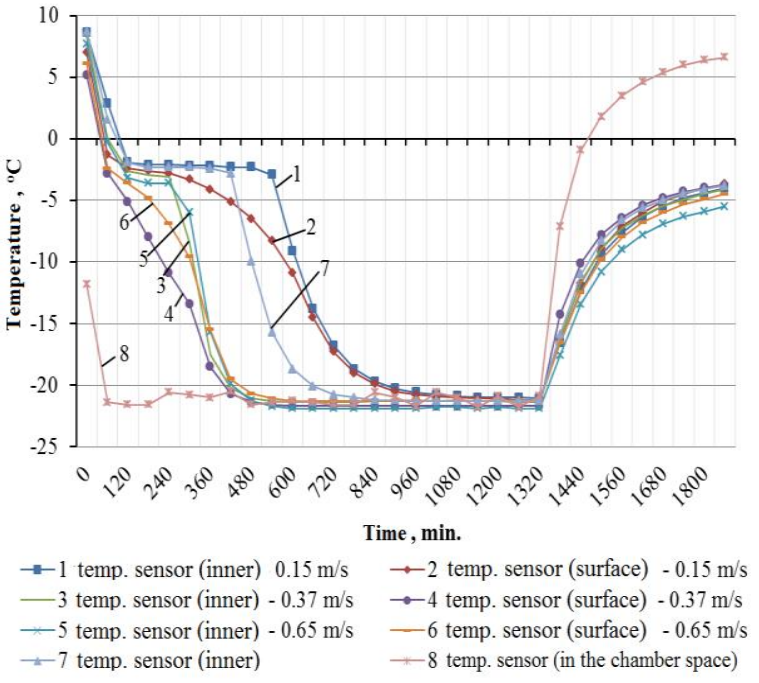

Fig. 2. Change of temperature in the central part and at the surface of a beet, when temperature in the climatic chamber was $-22{ }^{\circ} \mathrm{C} .1$ variation - 1, 2 temperature sensors - air flow velocity; 2 variation - 3, 4 temperature sensors - air flow velocity $0,65 \mathrm{~m} / \mathrm{s} ; 3$ variation - 5, 6 temperature sensors - air flow velocity $0,37 \mathrm{~m} / \mathrm{s} ; 4$ variation -7 temperature sensor - in a beet kept in the climatic chamber; 8 temperature sensor - air temperature in the climatic chamber

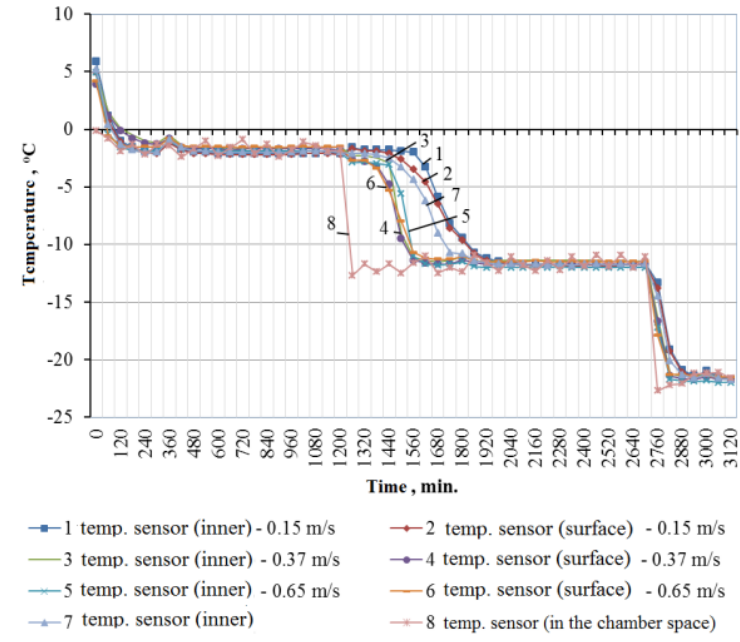

Fig. 3. Changes of temperature in the central part and at the surface of a beet, when temperature in the chamber was changed gradually $\left(-2{ }^{\circ} \mathrm{C} ;-12{ }^{\circ} \mathrm{C} ;-22\right.$ $\left.{ }^{\circ} \mathrm{C}\right) .1$ variant $-1,2$ temperature sensors - air flow velocity was $0,15 \mathrm{~m} / \mathrm{s} ; 2$ variant - 3, 4 temperature sensors - air flow velocity $0,65 \mathrm{~m} / \mathrm{s} ; 3$ variant -5 , 6 temperature sensors - air flow velocity $0,37 \mathrm{~m} / \mathrm{s}$; 4 variant -7 beetroot - in the climatic chamber; 8 temperature sensor - air temperature in the climatic chamber

The product was frozen from its initial temperature $\left(6^{\circ} \mathrm{C}\right)$ to cryoscopic temperature $\left(-2,5^{\circ} \mathrm{C}\right)$. In this section of a curve, temperature goes down sharply and change of temperature slows down when cryoscopic temperature is reached during the crystallisation process, but at the end of the crystallisation process, temperature of the frozen object falls dramatically till it reaches the temperature in the camera.

Fig. 3 shows heat removal from the object during freezing. The initial temperature depends on characteristics of a particular product and its moisture content $[9,13]$. This relates to release of heat at water conversion to ice. The deeper from the surface are temperature measurements, the slower is pace of temperature changes. The second part of a curve ( $2,5^{\circ} \mathrm{C}$ ) shows the very freezing process when ice crystals are formed. With increasing number of ice crystals, concentration of juice increases and the cryoscopic temperature goes down. Therefore, the second part of the curve deviates from a level line. In the range $-2,5 \ldots-22{ }^{\circ} \mathrm{C}$, the curve goes down followed by super-freezing of a product [13]. During thawing period, retention of temperature changes in beetroots can be observed. The temperature changes slowly, while re-crystallisation takes place - the heat energy is used for thawing of ices crystals.

Results of experimental research of freezing process are shown in Fig.3, when beetroots have been frozen at different air flow velocities and at different temperatures. Duration of the test was approximately 68 hours. Temperature in the climatic chamber had been changed gradually: on the first day $--2{ }^{\circ} \mathrm{C}$, the second day $--12{ }^{\circ} \mathrm{C}$ and on the third day $--22^{\circ} \mathrm{C}$.

The test data (Fig. 3) show that temperature in beets has reached $-2{ }^{\circ} \mathrm{C}$ and part of a beetroot was frozen, and water turned into ice crystals. The rest of beet juice was frozen at temperature $-10{ }^{\circ} \mathrm{C}$.

Figures 2 and 3 show that air flow velocity has a significant impact on freezing rate of the product. The higher is air flow velocity around an object, the higher is a freezing rate of a product. In both cases, the beetroots in a cylinder, wherein air flow velocity was the highest $(0,65 \mathrm{~m} / \mathrm{s}-3,4$ temperature sensors $)$, froze earlier and the longest time of freezing was determined for beets in the cylinder with the lowest air flow velocity $(0,15 \mathrm{~m} / \mathrm{s}-1,2$ temperature sensors).

Fig. 4 shows intensity of moisture evaporation during freezing at different air flow velocities and at constant temperature in the climatic chamber $-22{ }^{\circ} \mathrm{C}$. Beetroots were weighed 3 times during freezing.

In Fig. 4, we can see that at the beginning of freezing process (up to $145 \mathrm{~min}$.) moisture evaporation is more intensive from beets at the highest velocity of air flow (2'). Later (after 145 min.), the change was insignificant. 


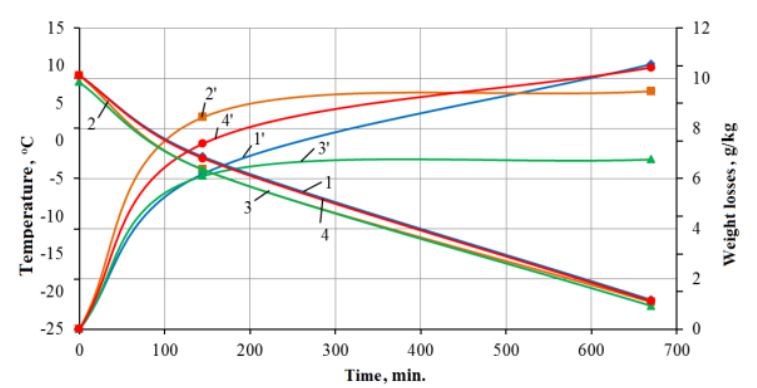

$\rightarrow 1^{\prime}$ - beetroot No. $2 \rightarrow-2^{\prime}$ - beetroot No $5 \rightarrow 3^{\prime}$ - beetroot No $8 \rightarrow 4^{\prime}$ - beetroot No 11 $\rightarrow-1-1$ temp. sensor $\rightarrow-2-3$ temp. sensor $\rightarrow-3-5$ temp. sensor $\rightarrow-4-7$ temp. sensor

Fig. 4. Dependences of weight of frozen beetroots and temperature changes on air flow velocity at $-22{ }^{\circ} \mathrm{C}$ temperature in a climatic chamber. 1-variation of temperature; 1 - variation of weight at velocity of air flow $0,15 \mathrm{~m} / \mathrm{s} ; 2$ - change of temperature; 2 'change of weight when air flow velocity was 0,65 $\mathrm{m} / \mathrm{s} ; 3$ - change of temperature; 3' - changes of weight at velocity of air flow equal to $0,37 \mathrm{~m} / \mathrm{s} ; 4$ change of temperature; $4^{\prime}$ - changes in weight of a beetroot in the chamber

The beetroots frozen at the lowest ambient air flow velocity level $\left(1^{\prime}\right)$ at the beginning of freezing process (up to $145 \mathrm{~min}$.) evaporated 26,72\% less moisture than frozen at the highest air flow velocity $\left(2^{6}\right)$. However, at the end of the process they evaporated more moisture by $10,21 \%$ in comparison to those frozen at the highest air velocity $\left(2^{\circ}\right)$. Increase of velocity of refrigerating air flow enhances When surface layers are covered with ice, the subsequent losses are insignificant.

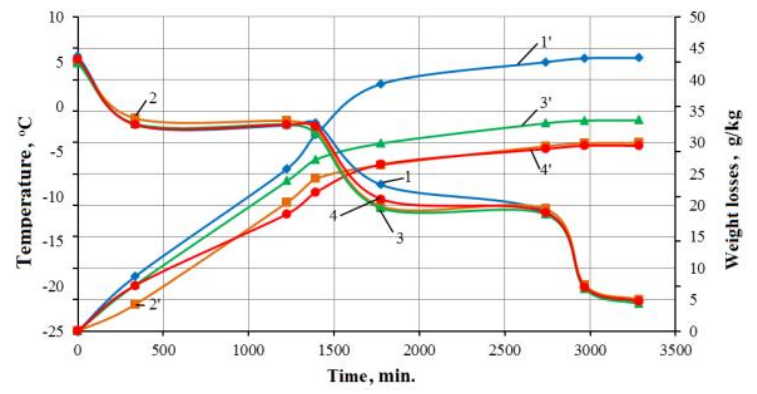

$\rightarrow 1^{\prime}$ - beetroot No $2 \rightarrow-2^{\prime}$ - beetroot No $5 \rightarrow 3^{\prime}$ - beetroot No $8 \rightarrow 4^{\prime}$ - beetroot No 11 $\rightarrow-1-1$ temp. sensor $\rightarrow-2-3$ temp. sensor $\rightarrow-3-5$ temp. sensor $\rightarrow-4-7$ temp. sensor

Fig. 5. Dependences of weight of freezing beetroots and temperature changes on air flow velocity, when temperature has been gradually changed $\left(-2{ }^{\circ} \mathrm{C}\right.$,$\left.12^{\circ} \mathrm{C} ;-22^{\circ} \mathrm{C}\right) .1$ - variation of temperature; $1^{\prime}-$ change of weight at velocity of air flow $0,15 \mathrm{~m} / \mathrm{s} ; 2$ - change of temperature; 2 " - change of weight when air flow velocity was $0,65 \mathrm{~m} / \mathrm{s} ; 3$ - change of temperature; 3" - changes of weight at velocity of air flow $0,37 \mathrm{~m} / \mathrm{s} ; 4$ - change of temperature; $4^{\circ}-$ change in weight of a beetroot in the chamber

Moisture evaporation was more intensive when temperature in the climatic chamber had been gradually reduced (Fig. 5): on the first day by $-2{ }^{\circ} \mathrm{C}$, on the second $--12{ }^{\circ} \mathrm{C}$ and on the third day $--22{ }^{\circ} \mathrm{C}$, because freezing time was longer till freezing-up of a surface layer. Less moisture evaporated from beets at higher velocities of refrigerating air flow, since surface layers of beetroots froze faster. Beetroots in environment with the highest air flow velocity $\left(2^{\circ}\right)$ evaporated $31,14 \%$ less moisture then froze at the lowest air flow velocity $\left(1^{\circ}\right)$ during freezing.

The test data showed that weight losses of frozen vegetables due to moisture evaporation were equal to: at temperature in the chamber $-22{ }^{\circ} \mathrm{C}-9,31 \pm 1,53$ $\mathrm{g} / \mathrm{kg}$; when temperature had been changed gradually $34,11 \pm 5,62 \mathrm{~g} / \mathrm{kg}$.

From Fig. 4 and 5 we can see that the higher velocity of refrigerated air flow, the higher is intensity of heat removal from frozen object.

\subsection{Moisture evaporation intensity test with peeled beets}

From the tests with whole and peeled beets (Fig. 6 and 7) it was determined that intensity of moisture evaporation depended on a peel and on stomata in it. Moisture evaporates not from the surface of a skin, but from intercellular vacuoles in plant tissue, which are in contact with environment through the stomata. Therefore, when a peel is removed from the product, moisture evaporation is more intensive.

From Fig. 6 we can see that peeled beetroots froze faster than the whole beetroots.

The test data showed that retardation of evaporation depended on a skin and on stomata in it as compared with evaporation from free water surface $\varepsilon_{\text {evp.av }}=0,50 \pm 0,02$. While freezing peeled beets, moisture evaporation is similar to evaporation from free water surface $\varepsilon_{\text {evp.av }} \approx 1$. Proportion of evaporation potential of a skin between whole (2'and $\left.4^{\circ}\right)$ and peeled $\left(1^{\prime}\right.$ and $\left.3^{\circ}\right)$ beetroots is as follows:

- at air flow velocity $0,15 \mathrm{~m} / \mathrm{s}-\varepsilon_{\text {evp }}=0,47-0,53$, average value $-\varepsilon_{\text {evp.av }}=0,50 \pm 0,02$;

- at air flow velocity equal to $0,65 \mathrm{~m} / \mathrm{s}-\varepsilon_{\text {evp }}=0,37$ - 0,45, average value $-\varepsilon_{\text {evp.av }}=0,42 \pm 0,04$.

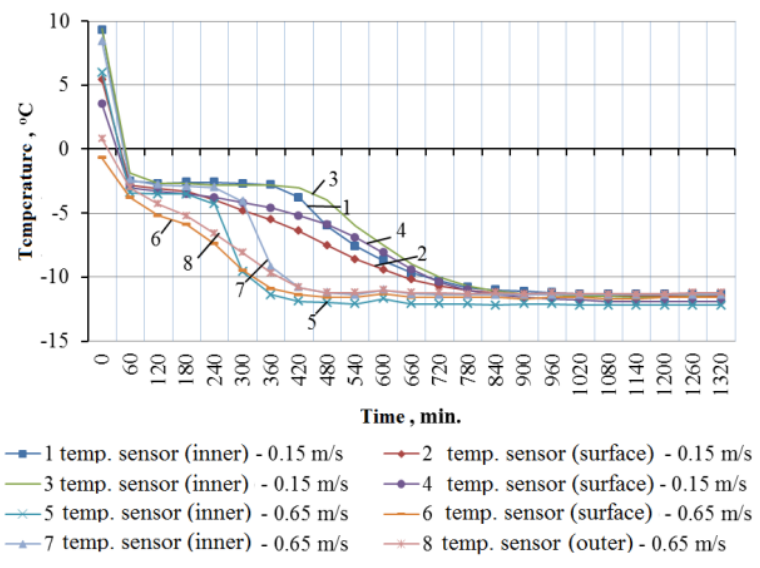

Fig 6. Change of temperature in the central part and at the surface of a beet, when temperature in the climatic chamber was $-12{ }^{\circ} \mathrm{C}$. 1,2 temperature sensors $-a$ peeled beet, and 3, 4 temperature sensors - a whole beet in air flow of $0,15 \mathrm{~m} / \mathrm{s} ; 5,6$ temperature sensors - a peeled beet, and 7, 8 temperature sensors - a whole beet at air flow velocity $0,65 \mathrm{~m} / \mathrm{s}$ 


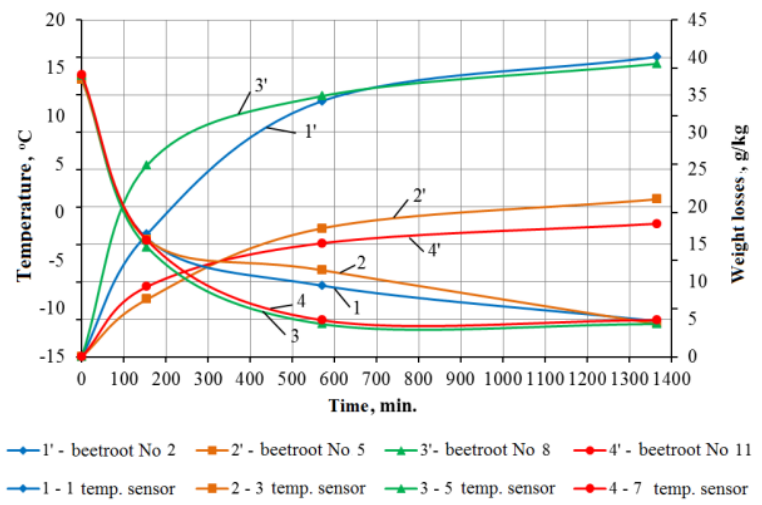

Fig. 7. Dependences of whole (2' and 4') and peeled (1' and 3 ') beets' weight and temperature on velocity of refrigerating air flow. 1 and 3 -variation of temperature; 1 ' and 3 - changes of weight at velocity of air flow $0,15 \mathrm{~m} / \mathrm{s} ; 2$ and 4 -variation of temperature; 2' and 4' - changes of weight when air flow velocity was $0,65 \mathrm{~m} / \mathrm{s}$

Intensity of moisture evaporation was not much dependant on air flow velocity.

Loss of moisture has a significant impact on infirmness of turgor, reduces resistance of the product tissue to micro-organisms and undermines commercial appearance.

\subsection{Results of turgor recovery test}

The turgor estimation test was carried out on a beetroot (T2) stored in normal conditions at $3-4{ }^{\circ} \mathrm{C}$ and on a beetroot (T1), kept one day in a climatic chamber where temperature was $-2{ }^{\circ} \mathrm{C}$.

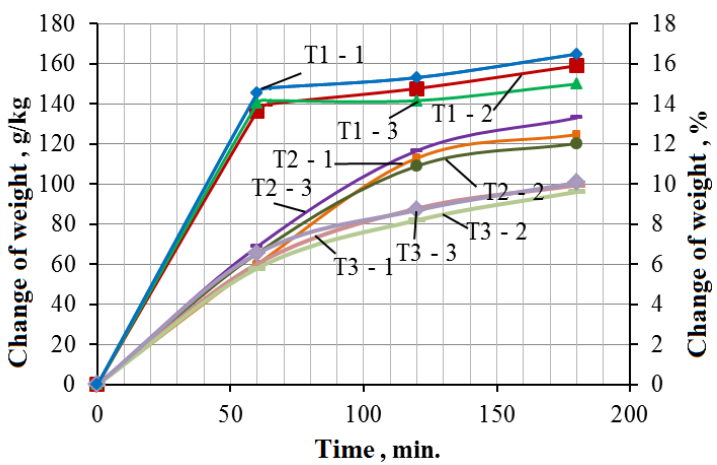

Fig 8. T1-1, T1-2, T1-3 - slices of a beet stored at $-2{ }^{\circ} \mathrm{C}$, T2-1, T2-2, T2-3 - slices of a stored in normal conditions. T3-1, T3-2, T3-3 - slices of a beet that have just been harvested from the soil

The test data shows (Fig. 8) that slices of the beet $\left(\mathrm{T} 1-\right.$ stored at $\left.-2{ }^{\circ} \mathrm{C}\right)$ have absorbed most of their water during the first hour and their weight changed insignificantly over the next two hours. Whereas slices of the beet (T2 - stored in normal conditions) absorbed water during the first two hours, the first beet (T1) water losses from the slices have been lower. Variation of moisture content of the beet (T2) stored under normal conditions is nearly similar to that of a beet, which has been just harvested from the soil (T3). The frozen beetroots lose more moisture than those kept under normal condition. Therefore, it can be stated that storage conditions affect losses of moisture from the product.

\section{Conclusions}

1. An air flow velocity has a great influence on freezing rate of vegetables. Intensity of moisture evaporation increases up to the moment of freezing-up of the surface layers.

4. During freezing of beetroot placed in an air flow (at $0,65 \mathrm{~m} / \mathrm{s}$ ), the amount of evaporated moisture was by $31,14 \%$ lower than under freezing at the minimal velocity of air flow $(0,15 \mathrm{~m} / \mathrm{s})$.

2. Determined weight losses of frozen vegetables due to moisture evaporation have been the following: at $-22{ }^{\circ} \mathrm{C}$, in the chamber the losses were $9,31 \pm 1,53 \mathrm{~g} / \mathrm{kg}$; when temperature in the chamber has been changed from -2 to $-22{ }^{\circ} \mathrm{C}$ (with $10{ }^{\circ} \mathrm{C}$ interval), the weight losses reached $34,11 \pm 5,62 \mathrm{~g} / \mathrm{kg}$.

3. A portion of moisture always evaporates from products of vegetable origin at freezing. Intensity rate of retardation of the evaporation process depends on a peel and on stomata on it. The moisture evaporation's retardation rate of the red beet peel $\varepsilon_{\text {evp.ap }}=0,50 \pm 0,02$. When the air velocity was $0,15 \mathrm{~m} / \mathrm{s}, \varepsilon_{\text {evp }}$ varied from 0,47 to 0,53 , whereas at an air flow velocity of 0.65 $\mathrm{m} / \mathrm{s}, \varepsilon_{\mathrm{evp}}=0,37-0,45$.

\section{References}

Gudavičiūtė D.. Maisto produktų laikymas. I dalis. Konservavimas šalčiu. Vilnius: - Vilniaus pedagoginio universiteto leidykla, 2010. $-64 \mathrm{p}$.

Viškelis P., Prasidedant uogų šaldymo sezonui // Sodo spalvos. 2006. Nr. 7. 49-51 p.

Viškelis P., Rubinskienė M. Uogų užšaldymo proceso modeliavimas ir optimizavimas. Sodininkystè ir daržininkystè. 2008. 27(3): 301-311 p.

Barbosa-Canovas G. V., Altunakar, Mejia-Lorio D.J. Freezing of fruit and vegetables. Food and agriculture organization of the United Nations. Rome, 2005. - 64 p.

Rubinskienė M. , Viškelis P. Vaisių ir uogų užšaldymas // Mano ūkis. 2006. Nr. 6. 46-47 p.

Raila A. Šviežios braškès ne tik vasarą. Ūkininko patarejjas, $2000 \mathrm{~m}$. kovo $25 \mathrm{~d}$. Nr. 35 (1023). - 10 p.

Shafiur Rahman M.. Handbook of Food Preservation: Second Edition. Taylor \& Francis Group, 2007. - 1068 p. http://dx.doi.org/10.1201/9781420017373

Brennan I. Brennan J. G. Food Processing Handbook. WILEY-VCH, 2006. 582 p.

Evans J. A. Frozen Food Science and Technology. Blackwell Publishing Ltd, 2008. 355 p. http://dx.doi.org/10.1002/9781444302325 
Tarptautiniu žodžiu žodynas. Prieiga per internetą: http://www.tzz.lt/t/turgoras.

Жадан В.3. Теоретические основы кондиционирования воздуха при хранении сочного растительного сырья. Москва, 1971. 155 р.

Vasiliauskas V.V. Šaldytuvai / Vadovèlis. Kaunas: Technologija, 2005. - 158 p.

Vasiliauskas V. V. Konservavimas šalčiu. Vilnius: Mokslas, 1999. - $168 \mathrm{p}$.

Kondratowicz J., Matusevičius P. Use of low temperatures for food preservation // Veterinarija ir zootechnika. T. 17 (39). 2002. - P. 88-92.

Goncalves E.M., Abreu M., Branda o T.R.S., Silva C.L.M. Degradation kinetics of colour, vitamin C and drip loss in frozen broccoli (Brassica oleracea L. ssp. Italica) during storage at isothermal and non-isothermal conditions // International Journal of Refrigeration. Volume 34, Issue 8, December 2011, P. 2136-2144. http://dx.doi.org/10.1016/j.ijrefrig.2011.06.006

Thakur N.S., Thakur N.K. (2000). Principles and method of preservation of fruits and vegetables // Postharvest Technology of Fruits and Vegetables: Handling, Processing, Fermentation and Waste Management. Indus Publishing company, P. 148-181.
Reid David S., Barrett Diane M.. Fruit Freezing // Processing fruits: science and technology. CRC Press, 2005. - P. 161-172.

PhD student Simona Paulikienė - Aleksandras Stulginskis University, Faculty of Agricultural Engineering, Institute of Energy and Biotechnology Engineering

\begin{tabular}{|c|c|}
\hline Address: & $\begin{array}{l}\begin{array}{l}\text { Studentuc g. 15, } \\
\text { Stulginskio } \\
\text { universitetas, } \\
\text { Akademijos mstl. LT-4324 Kauno } \\
\text { distr. Lithuania }\end{array}\end{array}$ \\
\hline $\begin{array}{l}\text { Tel. } \\
\text { E-mail: }\end{array}$ & $\begin{array}{l}\text { +370 } 67378300, \\
\text { semsimona@gmail.com }\end{array}$ \\
\hline
\end{tabular}

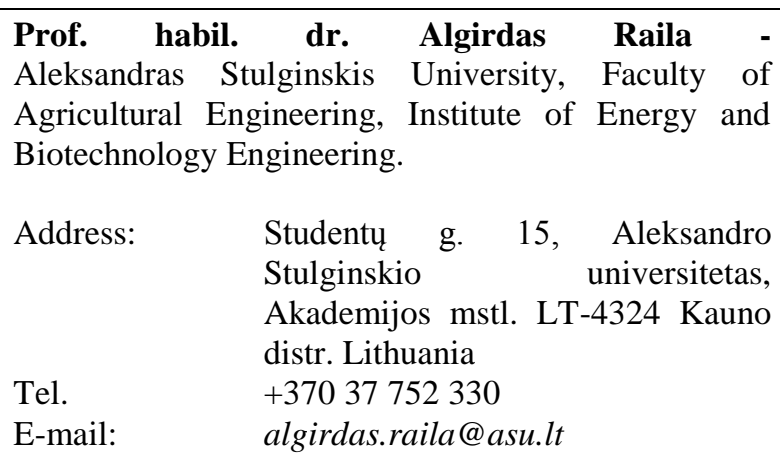

\title{
Daržovių užšaldymo proceso efektyvumo tyrimas
}

\author{
Simona Paulikienė ir Algirdas Raila
}

Energetikos ir biotechnologiju inžinerijos institutas, Aleksandro Stulginskio Universitetas, Kaunas, Lietuva

(gauta 2013 m. gruodžio mèn., priimtas spaudai 2014 m. rugsèjo mén.)

Augalinès kilmės produktų laikymo metu neišvengiami pasikeitimai, dèl kurių gali menkèti prekinè išvaizda, produktu maistinè verte, konsistencija, skonis ir aromatas. Viena iš tinkamiausiu technologiniu operacijų išlaikyti produktą kuo mažiau pakitusị - šaldymas. Šaldant augalinès kilmès produktus naudojama švaresnè gamybos technologija, t.y. sunaudojama mažiau energijos, geriau išsaugoma produkto kokybė, naudingosios maistinès ir biologiškai aktyvios medžiagos.

Daržoviu užšaldymo proceso tyrimai atlikti šaldant raudonuosius burokèlius. Burokèliai buvo šaldomi reguliuojamo mikroklimato aplinkoje - feutrone.

Užšaldant augalinės kilmès produktus visada išgarinama dalis drėgmės. Užšaldant daržoves oro srauto judejimo greitis turi didelę įtaką produkto užšalimo greičiui, taip pat didèja drègmès išgarinimo intensyvumas iki to momento, kol užšąlą produkto paviršiniai sluoksniai.

Garavimo stabdymo intensyvumas priklauso nuo žievelès ir joje esančiu žioteliu. Raudonuju burokèliu žievès drègmès garavimo stabdymo koeficientas $\varepsilon_{i s ̌ g . v i d}=0,50 \pm 0,02$. Kai: oro srauto judèjimo greitis buvo $0,15 \mathrm{~m} / \mathrm{s}-\varepsilon_{i \check{s g}}$ kito nuo 0,47 iki 0,53 , o esant oro srauto judèjimo greičiui $0,65 \mathrm{~m} / \mathrm{s}-\varepsilon_{i s ̌ g}=0,37-0,45$

Tyrimo tikslas - išanalizuoti daržovių (imant raudonụjų burokèlių pavyzdį) užšaldymo procesą, veikiant skirtingiems aplinkos veiksniams. 